\title{
The Effect of Guided Discovery and STAD Learning Models on Students' Critical Thinking and Scientific Process Skills on Environmental Pollution Topic in MAPN 4 Medan
}

\author{
Ayyub JW Prayogi \\ Biology Department \\ Postgraduate Program of Universitas \\ Negeri Medan \\ Medan, Indonesia \\ ayyubjw.prayogi@yahoo.com
}

\author{
Ely Djulia \\ Biology Department \\ Postgraduate Program of Universitas \\ Negeri Medan \\ Medan, Indonesia \\ djulia247@unimed.ac.id
}

\author{
Syahmi Edi \\ Biology Department \\ Postgraduate Program of Universitas \\ Negeri Medan \\ Medan, Indonesia \\ syahmiedibiologi@unimed.ac.id
}

\begin{abstract}
This study aimed to determine the effect of Guided Discovery and STAD learning models on students': (1) critical thinking skill; (2) scientific process skill in grade X of MAPN 4 Medan. The research method used was quasi-experimental with a sample of 3 classes determined by cluster random sampling. X-1 class was taught by Guided Discovery learning model, class $X-3$ was taught by STAD learning model and class X-2 (control) was taught by conventional learning model. The research instrument used was a test instrument for the results of critical thinking skill and scientific process skill in the form of essay tests. The data analysis technique used was Covariate Analysis (ANACOVA) at a significance level of $\alpha=0.05$ by using SPSS 21.0. The results showed: (1) there was a significant effect of the learning model on students' critical thinking skill $(F=4,410 ; P=0,015)$. The results of students' critical thinking skill who were taught by the Guided Discovery learning model $(83.61 \pm 7.33)$ were not significantly different with the STAD learning model $(80.71 \pm 8.67)(P=0.35)$ but differed significantly with conventional learning model (77.86 $\pm 10.16)(P=0.01)$ and students' critical thinking skill who were taught by the STAD learning model $(80.71 \pm 8.67)$ were not significantly different with conventional learning model $\mathbf{( 7 7 . 8 6} \pm$ 10.16) $(P=0.36)$. (2) There was a significant effect of the learning model on scientific process skill $(F=17,196 ; P=0,000)$. The students' scientific process skill who were taught by the Guided Discovery learning model $(87.36 \pm 5.74)$ were not significantly different with the STAD learning model $(84.77 \pm 5.54)(P=0.10)$ but differed significantly with the conventional learning model $(80.26 \pm 4.35)(P=0.00)$ and the students' scientific process skill who were taught by STAD learning model $(84.77 \pm 5.54)$ differed significantly with the conventional learning model $(80.26 \pm 4.35)$ $(P=0.00)$ As a follow-up of the results of this study it was expected that teachers can apply Guided Discovery and STAD learning models to environmental pollution topic in an effort to improve the results of students' critical thinking and scientific process skill.
\end{abstract}

Keywords: Guided Discovery, STAD, Critical Thinking Skill, Scientific Process Skill.

\section{INTRODUCTION}

Education is a necessity for humans, both formal and nonformal education. Education is a process that influences students to adapt themselves as best they can to their environment, thereby causing changes in themselves that function adequately in people's lives (Hamalik, 2007). Because education is an activity that involves many people including students, educators, administrators, community (stakeholders) and parents of students (Iskandar, 2009). In an effort to improve the quality of education, there are many factors or strategies that can be used to implement it.

One factor that influences the quality of education is the learning process. To improve the quality of learning can be done from various aspects including the learning process. One of the strategic issues at the beginning of this century is the Asean Economic Community. Entering the era of the Asean Economic Community (AEC) 2015, Indonesian stakeholders must naturally follow international standards in order to survive in this global era. This is evident from the results of several surveys conducted by international institutions such as the Trend in International Mathematics and Science Study (TIMSS) Indonesian students ranked 36th out of 49 countries in terms of conducting scientific procedures, while the Program for International Student Assessment (PISA) year 2015 which shows that Indonesia can only rank 69th of 76 countries.

According to Samatowo (2010), learning carried out by teacher places more emphasis on the aspects of understanding and knowledge while the aspects of analyzing, evaluating, and even creating a smaller fraction of the learning done. Learning is still teacher-oriented and students are not given the opportunity to develop critical thinking skills. Critical thinking is thinking reasonably and replicative with an emphasis on making decisions about what to believe or do. Students who think critically will be able to defend their opinions, make comparisons, draw conclusions, evaluate arguments and solve problems. 
According to Semiawan (1996) that science process skills are the ability of students to apply scientific methods in understanding, developing and discovering science. The classification of science process skills is divided into two namely basic and integrated process skills. Basic process skills consist of six skills, namely observing, classifying, predicting, measuring, inferring, and communicating. Whereas integrated process skills consist of identifying variables, making data tabulations, presenting data in graphical form, describing relationships between variables, collecting data, analyzing knowledge, developing hypotheses, defining variables and operations, designing research and carrying out experiments.

Guided discovery is a learning method that directs students to activities that can develop science process skills where students are guided to discover and investigate themselves about a science concept so that the knowledge and skills possessed by students are not the result of remembering a set of facts but rather their own findings. (Suryosubroto, 2002). While the STAD cooperative learning model emphasizes the activities and interactions between students to motivate each other and help each other in mastering subject matter in order to achieve maximum performance. The advantages of the STAD model include active students helping and motivating the spirit to succeed together, being active as a peer tutor to further enhance group success, eliminate selfishness and selfishness, increase mutual trust.

\section{MATERIALS AND METHODS}

\section{A. Research Design}

This research was a quasi-experimental research. The study design was an experimental design with a pretestposttest control group design.

\section{B. Samples}

The population in this study were all students of grade $\mathrm{X}$ MAPN 4 Medan. The sampling technique was cluster random sampling. The selected samples were class $\mathrm{X}-1$ given treatment with guided discovery learning, class $\mathrm{X}-3$ given treatment with STAD learning, and class X-2 as a control class / direct learning.

\section{Instruments}

The independent variables used were the Guided Discovery learning model and STAD learning model which were applied to the experimental classes and the direct learning model with the question and answer method and the discussion applied to the control class. The dependent variable in this study was critical thinking skills and scientific process skills consisting of observation, classification, prediction, interpretation, asking questions, hypothesizing, planning experiments, applying concepts, and communicating. Analysis of research data using the ANACOVA test and Tukey's advanced test with prerequisite tests using the Normality test with the Kolmogorov-Smirnov test and Homogeneity test with the Leven's test.

\section{RESULTS AND DISCUSSION}

\section{A. Results}

This research data in the form of an average score of critical thinking skills and scientific process skills to determine the effect of the application of Guided Discovery Learning, STAD and Direct Instruction Learning. The results of data processing showed that the average score of the results of tests of critical thinking skills and scientific process skills of students in the experimental group (guided discovery and STAD) was higher than the control group (lecture). The comparison of the average score of the results of tests of critical thinking skills in the guided discovery learning class was 83.61, in the STAD class was 80.71 while in the direct instruction learning class was 77.86. The comparison of the average score of the results of the scientific process skills test in the guided discovery class was 87.36 , in the STAD class was 84.77 while in the direct learning class was 80.26 .

Based on the average score, it can be concluded that the highest score was the group of guided discovery learning model. Thus that the used of guided discovery learning model had a better influence on students' critical thinking skills and scientific process skills.

Then the prerequisite analysis of the research data was carried out. Prerequisite analysis of research data was done by calculating the hypothesis test using the ANACOVA test technique. Hypothesis testing using the ANACOVA test was done after calculating the hypothesis prerequisite test, namely through the normality test and homogeneity test. Normality testing was performed to determine the data distribution which were normal or not. Recapitulation of the results of normality tests of students' critical thinking skills and scientific process skills can be seen in Tables 1 and 2 .

TABLE 1. RECAPITULATION OF THE NORMALITY TEST ON CRITICAL THINKING SKILLS

\begin{tabular}{cccc}
\hline \multirow{2}{*}{ No } & Learning Models & \multicolumn{2}{c}{ Kolmogorov - Smirnov } \\
\cline { 3 - 4 } & & Significance & Note \\
\hline 1. & Guided Discovery & 0.066 & Normal \\
\hline 2. & STAD & 0.189 & Normal \\
\hline 3. & DI (Conventional) & 0.172 & Normal \\
\hline
\end{tabular}

TABLE II. RECAPITULATION OF THE NORMALITY TEST ON SCIENTIFIC PROCESS SKILLS

\begin{tabular}{cccc}
\hline \multirow{2}{*}{ No } & Learning Models & \multicolumn{2}{c}{ Kolmogorov - Smirnov } \\
\cline { 3 - 4 } & & Significance & Note \\
\hline 1. & Guided Discovery & 0.147 & Normal \\
\hline 2. & STAD & 0.200 & Normal \\
\hline 3. & DI (Conventional) & 0.102 & Normal \\
\hline
\end{tabular}

Based on the calculation of normality test, it can be concluded that the distribution of data in the guided discovery class, STAD class and direct learning class on critical thinking 
skills and scientific process skills from normally distributed population.

Homogeneity variance test was performed to analyze whether the data from the sample population has homogeneous variance or not. Homogeneity testing was performed using the Leven's test. A summary of the homogeneity test can be seen in Tables III and IV.

TABLE III. RECAPITULATION OF HOMOGENEITY TEST FOR CRITICAL THINKING SKILLS

\begin{tabular}{c|c}
\hline \multicolumn{2}{c}{ Leven's Statistic } \\
\hline Sig. & Notes \\
\hline 0.145 & Homogeny \\
\hline
\end{tabular}
SCIENTIFIC PROCESS SKILLS

\begin{tabular}{c|c}
\hline \multicolumn{2}{|c}{ Leven's Statistic } \\
\hline Sig. & Notes \\
\hline 0.348 & Homogeny \\
\hline
\end{tabular}

Based on the calculation of variance homogeneity test value distribution of critical thinking skills and scientific process skills in the guided discovery class, STAD class and control class can be concluded that the data came from a homogeneous population.

Hypothesis testing was done after the data obtained was declared normal and homogeneous. Hypothesis testing was performed to determine whether the null hypothesis (Ho) submitted was accepted or rejected. Hypothesis testing was done by using ANACOVA test statistical techniques. The recapitulation of the results of the hypothesis test of critical thinking skills and the scientific process skills of the guided discovery, STAD and control classes can be seen in Table V.

\section{TABLE V. RECAPITULATION OF ANACOVA TEST FOR CRITICAL THINKING SKILLS}

\begin{tabular}{cccc}
\hline $\begin{array}{c}\text { Score } \\
\text { Recapitulation }\end{array}$ & F & Sig. & Notes \\
\hline $\begin{array}{c}\text { Critical Thinking } \\
\text { Skills }\end{array}$ & 4.410 & .015 & Ho was rejected \\
\hline
\end{tabular}

The results of the calculation of the hypothesis test using the ANACOVA test technique showed that there was a significant influence on the guided discovery class, STAD and control classes on critical thinking skills with Sig. $<0.05$ i.e. $\mathrm{F}=4.410 ; \mathrm{P}=0.015$. To know the treatment pairs being compared, did all treatments have different or the same effects, Tukey's further tests were performed. Recapitulation of the results of Tukey's further test critical thinking skills can be seen in table VI.

TABLE VI. RECAPITULATION OF ADVANCED TEST TO CRITICAL THINKING SKILLS

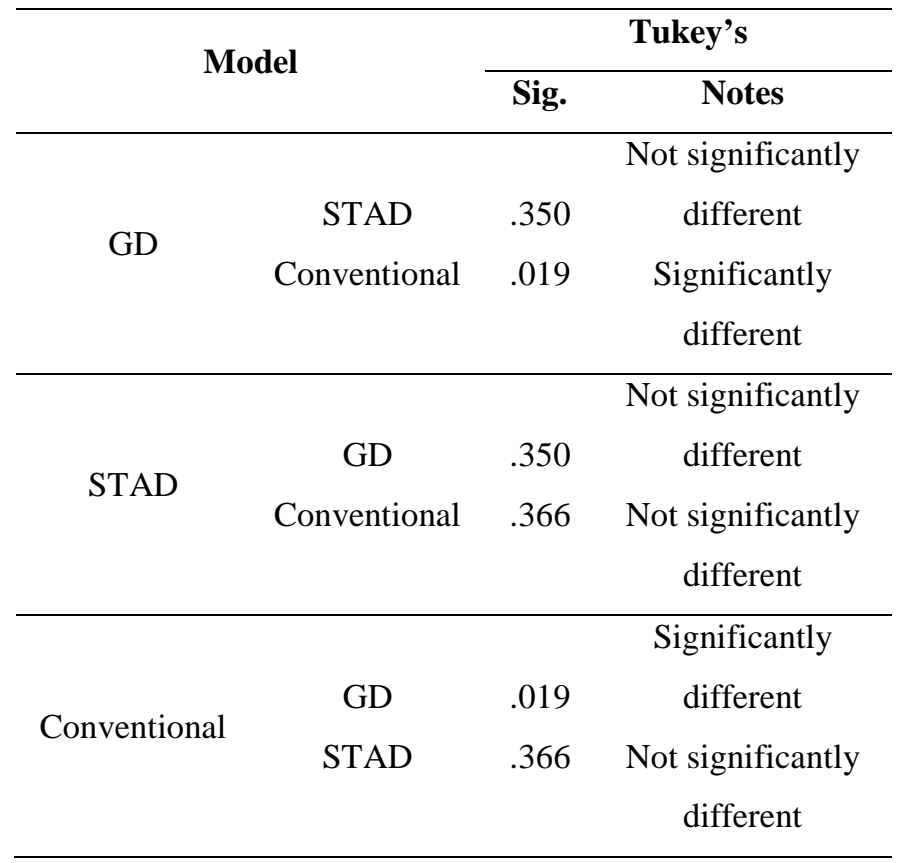

Based on further test calculations critical thinking skills results show that the critical thinking skills of students who were taught by guided discovery learning model were not significantly different from STAD learning model but were significantly different from conventional model. Students' critical thinking skills who were taught by STAD learning model were not significantly different from conventional learning model.

TABLE VII. RECAPITULATION OF ANACOVA TEST FOR SCIENTIFIC PROCESS SKILLS

\begin{tabular}{cccc}
\hline $\begin{array}{c}\text { Score } \\
\text { Recapitulation }\end{array}$ & F & Sig. & Notes \\
\hline $\begin{array}{c}\text { Scientific Process } \\
\text { Skills }\end{array}$ & 17.196 & .000 & Ho was rejected \\
\hline
\end{tabular}

The results of the calculation of the hypothesis test using the ANACOVA test technique showed that there was a significant influence on the guided discovery class, STAD and control class on scientific process skills with Sig. $<0.05$ i.e. $\mathrm{F}=17.196 ; \mathrm{P}=0,000$. To know the treatment pairs being compared, did all treatments have different or the same effects, Tukey's further tests were performed. Recapitulation of Tukey's advanced test results in students' science process skills can be seen in table VIII. 
TABLE VIII. RECAPITULATION OF ADVANCED TEST TO SCIENTIFIC PROCESS SKILLS

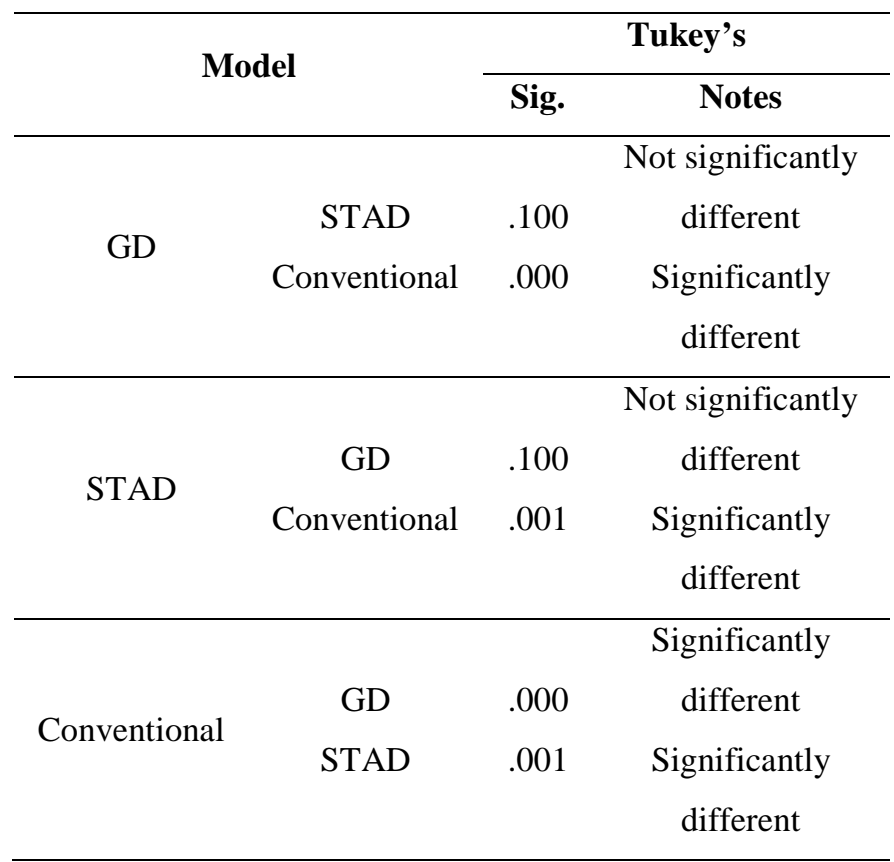

Based on further test calculations on the science process skills, the results show that the scientific process skills learned with the guided discovery model were not significantly different from the STAD learning model but were significantly different from the conventional model. The scientific process skills of students who were taught with STAD learning model differ significantly from conventional learning model.

\section{B. Discussion}

Based on the research that has been done, after the hypothesis testing there was a significant influence on the Guided Discovery, STAD and conventional learning models on critical thinking skills and science process skills on environmental pollution materials in class X MAPN 4 Medan.

Guided discovery learning model was a two way system learning model in which the learning process involves students and teachers. Students do the discovery and the teacher played a role in providing guidance (guided) by analyzing difficulties in solving problems faced by students. While the conventional learning model students only understand the concepts without being actively involved in the learning process. Besides Widura, et al (2015) students at the high school level who are educated with guided discovery learning had higher achievement than those taught using conventional methods. The same thing was stated by Haris, et al (2015) after the use of guided discovery learning atmosphere in the classroom became more effective. With the discovery activities on the guided discovery model students are actively involved in their cognitive processes so that students not only passively absorb the information but also contribute to the learning process.
This makes students become bolder and more confident in expressing their opinions and students are more open in their information.

While the learning process in the STAD class appears that students really active. This was indicated by the activity of students helping each other and sharing assignments in group discussions. Students also collected learning materials to solve problems during the learning process that was discussing environmental pollution. Then each group reports the results in class discussion. with student question and answer activities that were often done. All questions raised by students about problems in daily life that were relevant in accordance with the learning material. In this case they have the ability to think critically in these questions. While in conventional learning classes students are more passive, students rarely ask questions, just sit quietly listening to the material delivered by the teacher. Passive conditions make students feel bored, and less active in class. Samsuri's research (2017) conducted by applying the STAD cooperative learning model showed that the STAD cooperative model influences the critical thinking skills of students in grade VII Madrasah Tsanawiyah NW Pringgabaya 2016/2017 school year.

\section{CONCLUSION}

Based on the results of research and discussion, it was concluded that there was a significant influence on the Guided Discovery, STAD and Conventional Learning Models on critical thinking skills and scientific process skills on environmental pollution topic in grade X MAPN 4 Medan.

\section{ACKNOWLEDGMENT}

The author expresses the great gratitude to the supervisors: Dr. Ely Djulia, M.Pd. and Dr. Syahmi Edi, M.Si. who have provided constructive guidance and advice during this research.

\section{REFERENCES}

[1] Hamalik, O. 2007. Proses Belajar Mengajar, Jakarta: Bumi Aksara.

[2] Haris, F., Rinanto, Y., \& Fatmawati, U. (2015). Pengaruh Model Guided Discovery Learning Terhadap Kemampuan Berpikir Kritis Siswa Kelas X SMA Negeri Karang pandan Tahun Pelajaran 2013/2014. Jurnal Pendidikan Biologi 7(2): 114-122.

[3] Iskandar. 2009. Psikologi Pendidikan: Sebuah Orientasi Baru. Jakarta Gaung Persada Press.

[4] PISA. (2015). PISA Results Execitive Summary OECD (http//dx.doi.org/10.1787/42).

[5] Samatowo, U. (2010). Bagaimana Pembelajaran IPA di Sekolah Dasar. Jakarta: Depdiknas.

[6] Semiawan, C. 1996. Pendekatan Keterampilan Proses. Jakarta: PT. Gramedia

[7] Slameto. (2010). Belajar dan Faktor-Faktor yang Mempengaruhinya. Jakarta: Rineka Cipta

[8] Suryosubroto. 2002. Proses Belajar Mengajar di Sekolah. Jakarta: Rineka Cipta.

[9] Sugiyono. (2011). Metode Penelitian Kuantitatif Kualitatif dan R\&D. Bandung: Alfabeta.

[10] Widura, R. M., Karyanto, P., \&Ariyanto, J. (2015). Pengaruh Model Guided Discovery Learning Terhadap Kemampuan Berpikir Kritis 
Siswa Kelas X SMA Negeri 8 Surakarta Tahun Pelajaran 2014/2015.

Jurnal Bio-pedagogi 4(2): 25-30. 